\title{
Schizophrenia literacy amongst nursing students and nursing staff: an exploratory study
}

\author{
Bhavesh M. Lakdawala ${ }^{1}$, Ganpat K. Vankar ${ }^{2}$, Bharat N. Panchal ${ }^{3}$, Parag S. Shah ${ }^{4}$ \\ ${ }^{1}$ Associate Professor, Department of Psychiatry, GMERS Medical College and General Hospital, Gandhinagar, \\ Gujarat, India. \\ ${ }^{2}$ Professor, Department of Psychiatry, Sri Aurobindo Institute of Medical Sciences, Indore, Madhya Pradesh, India. \\ ${ }^{3}$ Professor, Department of Psychiatry, Government Medical College, Bhavnagar, Gujarat, India. \\ ${ }^{4}$ Professor, Department of Psychiatry, SMIMER Medical College, Surat, Gujarat, India. \\ E-mail-dr_bmlakdawala@yahoo.co.in
}

\begin{abstract}
Background: The term "Mental Health Literacy" refers to knowledge and beliefs about mental disorders which aid their recognition, management or prevention. It is an important component of Mental Health Primary Care (MHPC) training programs that aim to decrease the stigma of mental illness.

Aim and Objective: This study was aimed for assessing the levels of mental health literacy with respect to schizophrenia in nursing staff and nursing students and their views about effectiveness of various personnel and treatment modalities in schizophrenia.

Methodology: Total study population was 1011, out of which 615 were nursing students and 396 were nursing staff. They were working in various medical colleges of Gujarat. Participants completed a pre-test questionnaire in vernacular language at the beginning of MHPC training program. A proforma comprised of a case vignette of a person who met DSM-IV-TR criteria for schizophrenia, demographic characteristics of participants, their confidence level to help psychiatric patients, own or family member's experience of psychiatric illness. Attitudes towards patients with schizophrenia were assessed on 4 point scale measuring social distance. The items were related to participant readiness to live in neighbourhood, to socialize, to make friendship, to work with and to get the patient married in the family of respondent. Participants' knowledge about causation, manifestations and treatment of schizophrenia was tested on 10 true/ false statements. Each correct response yielded score 1 hence the possible score range was 0-10. Data were analyzed using appropriate statistical tests.

Results: Nursing students were more confident than nursing staff when it came to helping patients who were mentally ill. Knowledge levels about schizophrenia were similar between the two groups. Nursing students had a more positive attitude towards a patient with schizophrenia compared to nursing staff. A negative correlation between knowledge and attitude scores amongst the subjects was noted. There was no significant difference in opinions when respondents were compared on the basis of having and not having a member of their own family suffering from psychiatric illness.

Conclusion: The study serves as a baseline marker of schizophrenia literacy in nursing students and nursing staff across certain medical colleges in Gujarat. There is a need to implement a practical based psychiatric curriculum in nursing education to make future nurses aware about psychiatric illness and the methods of treatment available. This in turn would also increase awareness amongst the nursing students and nursing staff
\end{abstract}

Key words: Nursing students, nursing staff, schizophrenia, mental health literacy, knowledge, attitudes, awareness.

(Paper received $-3^{\text {rd }}$ August 2016, Peer review completed $-20^{\text {th }}$ August 2016, Accepted $-7^{\text {th }}$ September 2016) 


\section{INTRODUCTION}

The term "Mental Health Literacy" refers to knowledge and beliefs about mental disorders which aid their recognition, management or prevention. Mental health literacy includes the ability to recognize specific disorders; knowing how to seek mental health information; knowledge of risk factors and causes, of selftreatments, and of professional help available; and attitudes that promote recognition and appropriate help-seeking [1]. A high public level of mental health literacy and particularly in nursing personnel would make early recognition of and appropriate intervention in these disorders more likely. Many studies have shown that negative attitudes towards mental illness and particularly towards schizophrenia are widespread [2-6].

Stigma associated with patients suffering from a mental illness may also delay seeking treatment [7]. The belief that mental illness is incurable or self-inflicted can also be damaging, leading to patients not being referred for appropriate mental health care. Attitudes influence both professional and personal behavior. In particular, stigma and discrimination associated with mental illness and expressed by mental health professionals as well as the general public, results in the underuse of mental health services [8]. For effective health care to be delivered, it is crucial that health professionals are not hampered by prejudiced attitudes. While educational interventions can reduce stigma [9-10], stigmatizing opinions are not closely related to knowledge [2]. The main strategies for addressing psychiatric stigma and discrimination focus on protest, contact and education [11]. Short educational workshops can produce positive changes in participants' reported knowledge and attitudes towards people with mental health problems [12-13].

Stigma about psychiatric disorders in general and schizophrenia in particular is a global reality. Stigma leads to social exclusion, noncompliance to effective treatment and major obstacle to recovery. Several studies report that stigma is universal and involve not only lay persons but also various health professionals including psychiatrists, nursing personnel and health workers. Researchers have concluded that urban and rural societies differ in type of stigma [14-15]. Rural societies had a punitive model towards the severely mentally ill, while the urban group expressed a liberal view of severe mental illness. Urban Indians showed a strong link between stigma and not wishing to work with a mentally ill individual, whereas no such link existed for rural Indians [14]. In contrast in another study there was less stigma and more acceptance in those with limited literacy and women were more stigmatized [15]. There is a myth that people with schizophrenia are dangerous, violent and disruptive. This leads to social distancing or exclusion. Sadik reported that general public perception in Iraq is that mentally ill people are usually dangerous [16].

There are studies which suggest that increased MH Literacy may lead to positive attitudes towards people with schizophrenia. Lam and others [17] studied that Between pre- and post-test there was significant improvement in the recognition of mental disorders, beliefs about treatment became more concordant with health professionals, and negative attitudes reduced in Chinese community in Melbourne. In contrast Esterberg and colleagues [18] noted that knowledge and social distance scores were not significantly correlated. Angermeyer and others [19] concluded that parallel to an increase in the public's tendency to endorse biological causes, an increase in the desire for social distance from people with schizophrenia was found.

Lay people and professionals have different beliefs about various non pharmacological and pharmacological interventions and who can help people with of Schizophrenia and that can have a major impact in prognosis. Researchers have noted that the training course improved participants' ability to recognize a mental disorder in a vignette, and reduced participants' faith in unhelpful and potentially harmful pharmacological interventions. There was evidence of a minor reduction in stigmatizing attitudes, and it was unclear if the training resulted in a change in participants' faith in recovery following treatment [20]. In a study by a nursing student it was reported that there were significant improvement over time in nursing student's views about the helpfulness of professional and lay interventions, their opinions about the helpfulness of mental health and other medications, and the usefulness of activity and nonpharmacological interventions [21]. 


\section{AIM AND OBJECTIVE}

This study was aimed for assessing the levels of Mental Health Literacy (knowledge and attitude) with respect to schizophrenia among nursing students and nursing staff and their views about effectiveness of various personnel and treatment modalities in schizophrenia.

\section{METHODOLOGY}

The participants were nursing staff from General Hospital as well as nursing students from various colleges in Gujarat. All of them attended Mental Health Primary Care (MHPC) training program conducted by Department of Psychiatry of Medical Colleges for 4 years duration from 2008 to 2011. Institution's Ethics Committee (IEC) permission was taken before starting MHPC training program. Purpose of the program was informed and consent was taken from participants before participation in the program. Participants were ensured of the confidentiality of the information provided.

\section{Instrument used in the study}

Participants completed a pre test questionnaire in vernacular language at the beginning of MHPC training program. Questionnaire was designed by expert psychiatrists of various medical colleges of Gujarat and was standardized by the experts in the field of psychiatry. A Proforma comprised of demographic characteristics of participants, their confidence level to help psychiatric patients, own or family member's experience of psychiatric illness.

A case vignette of a person who met DSM-IV-TR criteria for schizophrenia was given and the participant was asked to name the illness. This was followed by questions regarding among various persons who can help and what can help. Attitudes towards patients with schizophrenia were assessed on 4 point scale measuring social distance. The items were related to participant readiness to live in neighborhood, to socialize, to make friendship, to work with and to get the patient married in the family of respondent. Participants' knowledge about causation, manifestations and treatment of schizophrenia was tested on 10 true/ false statements. Each correct response yielded score 1 hence the possible score range was 0-10.

\section{STATISTICAL ANALYSIS}

The data was collected and stored on an excel sheet. The quantitative data were analyzed by "student's t test" and qualitative data was analyzed using "Chi square test". All the participants' knowledge scores and corresponding attitude scores were examined using "Spearman's Correlation test". Data were analyzed using SPSS version 15 . $p$ value of $<0.05$ was considered statistically significant.

\section{RESULTS}

\section{Subject Characteristics}

One thousand and three hundred nursing students and nursing staff were trained under program and 1011 completed proformas were analyzed. Out of them 615 were nursing students and 396 were nursing staff. Of the 615 nursing students $484(78.7 \%)$ were females and 131(21.3\%) were males. Of the 396 nursing staff $366(92.4 \%)$ were females and $30(7.6 \%)$ were males. Females were over-represented among nursing staff as compared to nursing students $(\mathrm{p}<0.0001)$

Most nursing students were of 20-22 years of age and most nursing staff were of 22-58 years age group. 46 (7.5\%) of nursing students and $11(2.8 \%)$ of nursing staff reported that they had a psychiatric illness in past. $60(9.8 \%)$ of nursing students and $28(7.1 \%)$ of nursing staff reported that they had a positive family history of a psychiatric illness. Thus more Nursing students compared to nursing staff reported that they suffered from psychiatric illness $(p=0.0015)$. Nursing students were more confident as compared to nursing staff in helping mentally ill patients. (Table 1)

\section{Knowledge about Schizophrenia}

Indian Journal of Mental Health 2016;3(4) 
Out of all participants, $55.4 \%$ of nursing students and $30.6 \%$ of nursing staff correctly named disorder as "Schizophrenia" in the case vignette $(p<0.0001)$. Score ranged from 0 to 8 with mean 4.69 ( \pm 1.4$)$ for all subjects. Nursing students score ranged from 1 to 8 with mean $4.68( \pm 1.33)$ while nursing staffs score ranged from 0 to 8 with mean $4.69( \pm 1.49)$. Knowledge level was almost similar $(\mathrm{t}=0.1113, \mathrm{df}=1009$, two-tailed $\mathrm{p}$ value $=0.9114)$. (Table 2$)$

\begin{tabular}{|c|c|c|c|c|c|c|}
\hline Confidence that they can help & $\begin{array}{l}\text { Not at all } \\
\text { (\%) }\end{array}$ & $\begin{array}{l}\text { Little } \\
\text { (\%) }\end{array}$ & $\begin{array}{l}\text { Some } \\
\text { What } \\
\text { (\%) }\end{array}$ & $\begin{array}{l}\text { Very much } \\
(\%)\end{array}$ & $\begin{array}{l}\text { Quite } \\
\text { (\%) }\end{array}$ & $\begin{array}{l}\text { No } \\
\text { Resp. } \\
(\%)\end{array}$ \\
\hline Student $(n=615)$ & 0.8 & 8.9 & 19.0 & 47.3 & 11.7 & 12.3 \\
\hline Staff $(n=396)$ & 2.0 & 10.1 & 31.8 & 42.9 & 6.1 & 7.1 \\
\hline
\end{tabular}

\section{Who can help a patient with Schizophrenia}

For question of whether the patient in the vignette required professional help from an expert, 96.9\% of nursing students and $98.2 \%$ of nursing staff said "yes". Psychiatrist, clinical psychologist and nurses were considered helpful to patient of schizophrenia by $>90 \%$ of respondents in both the groups.

Family doctor and social worker were considered helpful by approximately $80 \%$ and $60 \%$ of participants respectively in both groups.

Pharmacist, homeopath doctor and ayurvedic doctor were considered helpful by $<30 \%$ of participants. For the latter two, large proportions of participants of both the groups were uncertain.

Saint/religious leaders and faith healers were considered harmful by around $50 \%$ and $70 \%$ of students respectively. While one third of staff considered the former helpful, around $70 \%$ staff considered the latter harmful. (Table 3)

\begin{tabular}{|c|c|}
\hline \multicolumn{2}{|c|}{ Table 2-Knowledge about psychotic disorders } \\
Knowledge Item & Correct Answers (\%) \\
\hline Patients with psychiatric illness should be treated in community hospitals & 22.4 \\
\hline Most of the patients of psychiatric illness are violent & 76.6 \\
\hline All children of Schizophrenia patient will suffer from Schizophrenia & 87.8 \\
\hline The person who wants to commit suicide never tells others & 34.6 \\
\hline Hearing voices of people which others can't hear is a symptom of & 76.0 \\
\hline Schizophrenia & 20.5 \\
\hline Mentally ill person is eligible for benefits if his disability is at least $60 \%$ & 16.5 \\
\hline ECT will cause permanent loss of memory & 27.8 \\
\hline Main etiologies for psychotic disorders are biological factors & 50.6 \\
\hline Not interested in any work is an important symptom of Schizophrenia & 55.8 \\
\hline Most of the medications of psychiatric illnesses are addictive & \\
\hline
\end{tabular}

\section{What can help patient with Schizophrenia}

Around $40-90 \%$ in both groups said that exercise, yoga, hypnosis and stopping alcohol can help the patient with Schizophrenia and occasional use of alcohol was considered harmful by $70 \%$ in both groups. Around $85 \%$ and $75 \%$ in both groups said that "admission in psychiatry department of general hospitals" and "admission in mental hospital" respectively can help the patient with Schizophrenia. Around one third in both groups said that "special diet" can help the patient with Schizophrenia. (Table 4)

\section{Attitude towards schizophrenia}

\section{Social Distance towards Schizophrenia patient}

As shown in table 5 , nursing students had more positive attitude towards Patient with schizophrenia compared to nursing staff on items like living in neighborhood, socializing, making friendship and working together. However on item on marriage, staff had slightly more positive attitude. 
Person experience of own or family member's psychiatric disorder and Attitude towards patients with Schizophrenia

Respondents' attitude for first four items was positive while attitude for fifth item that "readiness to marry within family of schizophrenia" was negative. But there was no statistically significant difference in attitude between respondents having and not having psychiatric illness to self and in family.

\begin{tabular}{|c|c|c|c|c|c|c|}
\hline Who can Help & Subject & $\begin{array}{l}\text { Says Helps } \\
\text { (\%) }\end{array}$ & $\begin{array}{c}\text { Says Harms } \\
(\%)\end{array}$ & Not Sure (\%) & $\begin{array}{c}\text { No response } \\
(\%)\end{array}$ & $P$ value \\
\hline Family Doctor & $\begin{array}{l}\text { Student } \\
\text { Staff }\end{array}$ & $\begin{array}{l}79.7 \\
84.6\end{array}$ & $\begin{array}{l}3.7 \\
2.0\end{array}$ & $\begin{array}{c}13.3 \\
8.3\end{array}$ & $\begin{array}{l}3.3 \\
5.1\end{array}$ & $0.016^{*}$ \\
\hline Pharmacist & $\begin{array}{c}\text { Student } \\
\text { Staff }\end{array}$ & $\begin{array}{l}27.2 \\
30.8 \\
\end{array}$ & $\begin{array}{l}31.7 \\
24.8 \\
\end{array}$ & $\begin{array}{l}32.8 \\
28.5 \\
\end{array}$ & $\begin{array}{c}8.3 \\
15.9 \\
\end{array}$ & $0.0021^{*}$ \\
\hline Social Worker & $\begin{array}{c}\text { Student } \\
\text { Staff }\end{array}$ & $\begin{array}{l}62.9 \\
64.6\end{array}$ & $\begin{array}{l}8.3 \\
7.1\end{array}$ & $\begin{array}{l}20.5 \\
17.4\end{array}$ & $\begin{array}{c}8.3 \\
10.9\end{array}$ & 0.3273 \\
\hline Psychiatrist & $\begin{array}{c}\text { Student } \\
\text { Staff }\end{array}$ & $\begin{array}{l}98.3 \\
98.4\end{array}$ & $\begin{array}{c}0 \\
0.3\end{array}$ & $\begin{array}{l}0.5 \\
0.3\end{array}$ & $\begin{array}{l}1.2 \\
1.0\end{array}$ & 0.5878 \\
\hline $\begin{array}{c}\text { Clinical } \\
\text { psychologist }\end{array}$ & $\begin{array}{c}\text { Student } \\
\text { Staff }\end{array}$ & $\begin{array}{l}91.1 \\
91.3 \\
\end{array}$ & $\begin{array}{l}1.5 \\
0.8 \\
\end{array}$ & $\begin{array}{l}2.7 \\
1.3 \\
\end{array}$ & $\begin{array}{l}4.7 \\
6.6 \\
\end{array}$ & 0.2029 \\
\hline Nurse & $\begin{array}{c}\text { Student } \\
\text { Staff }\end{array}$ & $\begin{array}{l}90.4 \\
93.9\end{array}$ & $\begin{array}{l}1.0 \\
0.8\end{array}$ & $\begin{array}{l}5.9 \\
1.0\end{array}$ & $\begin{array}{l}2.7 \\
4.3\end{array}$ & $0.0009 *$ \\
\hline $\begin{array}{c}\text { Homeopath } \\
\text { Doctor }\end{array}$ & $\begin{array}{c}\text { Student } \\
\text { Staff }\end{array}$ & $\begin{array}{l}21.1 \\
26.8\end{array}$ & $\begin{array}{l}10.6 \\
9.3\end{array}$ & $\begin{array}{l}59.7 \\
49.8\end{array}$ & $\begin{array}{c}8.6 \\
14.1\end{array}$ & $0.0027^{*}$ \\
\hline $\begin{array}{c}\text { Ayurvedic } \\
\text { Doctor }\end{array}$ & $\begin{array}{c}\text { Student } \\
\text { Staff }\end{array}$ & $\begin{array}{l}20.3 \\
26.5 \\
\end{array}$ & $\begin{array}{l}13.3 \\
10.7 \\
\end{array}$ & $\begin{array}{l}58.2 \\
48.7 \\
\end{array}$ & $\begin{array}{c}8.2 \\
14.1 \\
\end{array}$ & $0.00048^{*}$ \\
\hline Saint & $\begin{array}{l}\text { Student } \\
\text { Staff }\end{array}$ & $\begin{array}{l}11.9 \\
32.3\end{array}$ & $\begin{array}{l}48.8 \\
21.5\end{array}$ & $\begin{array}{l}31.5 \\
34.3\end{array}$ & $\begin{array}{c}7.8 \\
11.9\end{array}$ & $<0.0001^{\star}$ \\
\hline Faith Healer & $\begin{array}{l}\text { Student } \\
\text { Staff }\end{array}$ & $\begin{array}{l}2.8 \\
2.3\end{array}$ & $\begin{array}{l}76.9 \\
71.0\end{array}$ & $\begin{array}{l}15.9 \\
14.6\end{array}$ & $\begin{array}{c}4.4 \\
12.1\end{array}$ & $0.0001^{*}$ \\
\hline
\end{tabular}

*significant $(\mathrm{p}<0.05)$ Chi square test used in the assessment (Staff $\mathrm{N}=396$, Student $\mathrm{N}=615$ )

\begin{tabular}{|c|c|c|c|c|c|c|}
\hline $\begin{array}{c}\text { What } \\
\text { can help }\end{array}$ & $\begin{array}{c}\text { Subject } \\
(\%)\end{array}$ & $\begin{array}{c}\text { Help } \\
(\%)\end{array}$ & $\begin{array}{c}\text { Harm } \\
(\%)\end{array}$ & $\begin{array}{c}\text { Not sure } \\
\text { (\%) }\end{array}$ & $\begin{array}{c}\text { No } \\
\text { Response } \\
(\%)\end{array}$ & P value \\
\hline Vitamin & $\begin{array}{c}\text { Student } \\
\text { Staff }\end{array}$ & $\begin{array}{l}57.4 \\
54.0\end{array}$ & $\begin{array}{l}2.0 \\
0.8\end{array}$ & $\begin{array}{l}30.7 \\
31.3\end{array}$ & $\begin{array}{c}9.9 \\
13.9\end{array}$ & 0.105 \\
\hline Antidepressants & $\begin{array}{c}\text { Student } \\
\text { Staff }\end{array}$ & $\begin{array}{l}69.6 \\
71.7\end{array}$ & $\begin{array}{l}14.7 \\
10.9\end{array}$ & $\begin{array}{c}10.2 \\
7.3\end{array}$ & $\begin{array}{c}5.5 \\
10.1\end{array}$ & $0.007^{*}$ \\
\hline Analgesic & $\begin{array}{c}\text { Student } \\
\text { Staff }\end{array}$ & $\begin{array}{l}21.3 \\
23.7\end{array}$ & $\begin{array}{l}37.7 \\
32.6\end{array}$ & $\begin{array}{l}29.3 \\
27.5\end{array}$ & $\begin{array}{l}11.7 \\
16.2\end{array}$ & 0.1005 \\
\hline Antibiotics & $\begin{array}{c}\text { Student } \\
\text { Staff }\end{array}$ & $\begin{array}{l}16.6 \\
15.7\end{array}$ & $\begin{array}{l}32.5 \\
31.1\end{array}$ & $\begin{array}{l}38.2 \\
34.1\end{array}$ & $\begin{array}{l}12.7 \\
19.1\end{array}$ & 0.0438 \\
\hline Antipsychotics & $\begin{array}{c}\text { Student } \\
\text { Staff }\end{array}$ & $\begin{array}{l}44.2 \\
40.7\end{array}$ & $\begin{array}{l}21.2 \\
24.2\end{array}$ & $\begin{array}{l}16.4 \\
12.1\end{array}$ & $\begin{array}{l}18.2 \\
23.0\end{array}$ & 0.057 \\
\hline Antianxiety & $\begin{array}{c}\text { Student } \\
\text { Staff }\end{array}$ & $\begin{array}{l}67.3 \\
70.7 \\
\end{array}$ & $\begin{array}{l}16.3 \\
12.6 \\
\end{array}$ & $\begin{array}{c}47.6 \\
6.6 \\
\end{array}$ & $\begin{array}{c}8.8 \\
10.1 \\
\end{array}$ & 0.3359 \\
\hline Sedatives & $\begin{array}{c}\text { Student } \\
\text { Staff }\end{array}$ & $\begin{array}{l}58.2 \\
63.6\end{array}$ & $\begin{array}{l}28.1 \\
23.0\end{array}$ & $\begin{array}{l}6.2 \\
5.6\end{array}$ & $\begin{array}{l}7.5 \\
7.8 \\
\end{array}$ & 0.2818 \\
\hline Exercise & $\begin{array}{c}\text { Student } \\
\text { Staff }\end{array}$ & $\begin{array}{l}74.2 \\
64.4 \\
\end{array}$ & $\begin{array}{l}2.6 \\
3.0 \\
\end{array}$ & $\begin{array}{l}13.6 \\
19.9 \\
\end{array}$ & $\begin{array}{c}7.6 \\
12.7 \\
\end{array}$ & $0.006^{*}$ \\
\hline
\end{tabular}




\begin{tabular}{|c|c|c|c|c|c|c|}
\hline $\begin{array}{c}\text { What } \\
\text { can help }\end{array}$ & $\begin{array}{c}\text { Subject } \\
\mathbf{( \% )}\end{array}$ & $\begin{array}{c}\text { Help } \\
\mathbf{( \% )}\end{array}$ & $\begin{array}{c}\text { Harm } \\
\mathbf{( \% )}\end{array}$ & $\begin{array}{c}\text { Not sure } \\
\mathbf{( \% )}\end{array}$ & $\begin{array}{c}\text { No } \\
\text { Response } \\
\mathbf{( \% )}\end{array}$ & P value \\
\hline Yoga & Student & 89.4 & 1.8 & 3.9 & 4.9 & 0.182 \\
& Staff & 85.3 & 2.3 & 4.3 & 8.1 & \\
\hline Stop Alcohol & Student & 85.4 & 5.0 & 4.4 & 5.2 & $0.0001^{*}$ \\
& Staff & 71.5 & 11.5 & 6.6 & 10.4 & \\
\hline Occasional Use of & Student & 7.0 & 79.6 & 6.2 & 7.2 & $0.0002^{*}$ \\
Alcohol & Staff & 6.8 & 69.2 & 10.1 & 13.9 & \\
\hline Hypnosis & Student & 42.0 & 18.5 & 20.5 & 19.0 & 0.147 \\
& Staff & 36.1 & 20.7 & 19.4 & 23.8 & \\
\hline E.C.T. & Student & 76.1 & 11.7 & 5.9 & 6.3 & 0.096 \\
& Staff & 71.2 & 11.9 & 6.3 & 9.6 & \\
\hline C.B.T. & Student & 58.3 & 5.9 & 11.9 & 23.9 & 0.266 \\
& Staff & 58.1 & 3.8 & 10.3 & 27.8 & \\
\hline Admission in & Student & 86.3 & 4.6 & 4.7 & 4.4 & 0.209 \\
Psychiatry Dept. & Staff & 88.9 & 2.0 & 4.8 & 4.3 & \\
\hline Admission in & Student & 79.7 & 10.6 & 4.7 & 5.0 & $0.025^{*}$ \\
Mental Hospital & Staff & 73.0 & 11.4 & 8.8 & 6.8 & \\
\hline Special diet & Student & 31.5 & 8.9 & 47.5 & 12.1 & $0.001^{*}$ \\
& Staff & 37.9 & 3.0 & 45.5 & 13.6 & \\
\hline
\end{tabular}

(*significant $\mathrm{p}<0.05$, Chi square test used in the assessment)

\begin{tabular}{|c|c|c|c|c|c|c|c|}
\hline \multicolumn{8}{|c|}{ Table 5 - Attitude towards Patient with Schizophrenia } \\
$\begin{array}{c}\text { How much } \\
\text { ready }\end{array}$ & Subject & $\begin{array}{c}\text { Definite } \\
\text { Yes (\%) }\end{array}$ & $\begin{array}{c}\text { Perhaps } \\
\text { Yes (\%) }\end{array}$ & $\begin{array}{c}\text { Perhaps } \\
\text { No (\%) }\end{array}$ & $\begin{array}{c}\text { Definite } \\
\text { No (\%) }\end{array}$ & $\begin{array}{c}\text { No Res } \\
\text { (\%) }\end{array}$ & P Value \\
\hline $\begin{array}{c}\text { To stay in } \\
\text { neighborhood } \\
\text { with }\end{array}$ & Student & 73.7 & 18.8 & 4.4 & 2.0 & 1.1 & $0.0001^{*}$ \\
\hline Staff & 58.3 & 31.3 & 5.8 & 3.8 & 0.8 & \\
\hline To socialize with & Student & 82.1 & 12.8 & 2.9 & 1.4 & 0.8 & $0.00001^{*}$ \\
To make & Staff & 66.4 & 24.5 & 5.3 & 3.0 & 0.8 & \\
\hline To work with & Student & 74.6 & 17.7 & 5.0 & 1.7 & 1.0 & $<0.00001^{*}$ \\
\hline To marry with in & Staff & 56.1 & 33.3 & 7.3 & 3.0 & 0.3 & \\
family & Student & 63.9 & 25.4 & 5.5 & 4.1 & 1.1 & $0.00017^{*}$ \\
\hline
\end{tabular}

( ${ }^{*}$ significant $\mathrm{p}<0.05$, Chi square test used in the assessment)

Table 6 shows almost similar social distance attitude in parameters of attitude between two groups who had belief that most of the patients with psychiatric illness are violent and who had not such belief. The exception was marriage in the family of patient, those who perceived patient as violent, more often endorsed marriage of person in family.

\section{Knowledge and Attitude: Relationship}

All the subjects' knowledge scores and corresponding attitude scores were examined. There was significant negative correlation between knowledge and attitudes as shown in Table 7. 


\begin{tabular}{|c|c|c|c|c|}
\hline & How much ready & Subject & $\begin{array}{c}\text { Definitely } \\
\text { Yes (\%) }\end{array}$ & $\begin{array}{c}\text { Other responses } \\
(\%)\end{array}$ \\
\hline 1 & $\begin{array}{c}\text { To stay in neighborhood } \\
\text { with }\end{array}$ & $\begin{array}{c}\text { Violent } \\
\text { Not violent }\end{array}$ & $\begin{array}{l}162(68.4) \\
522(67.4)\end{array}$ & $\begin{array}{l}75(31.6) \\
252(32.6)\end{array}$ \\
\hline 2 & To socialize with & $\begin{array}{c}\text { Violent } \\
\text { Not violent }\end{array}$ & $\begin{array}{l}171(72.2) \\
597(71.1)\end{array}$ & $\begin{array}{c}66(27.8) \\
177(28.9)\end{array}$ \\
\hline 3 & To make friendship with & $\begin{array}{c}\text { Violent } \\
\text { Not violent }\end{array}$ & $\begin{array}{l}153(64.6) \\
528(68.2)\end{array}$ & $\begin{array}{l}84(35.4) \\
246(31.8)\end{array}$ \\
\hline 4 & To work with & $\begin{array}{c}\text { Violent } \\
\text { Not violent }\end{array}$ & $\begin{array}{l}132(55.7) \\
464(59.9)\end{array}$ & $\begin{array}{l}105(44.3) \\
310(40.1)\end{array}$ \\
\hline 5 & To marry with in family & $\begin{array}{c}\text { Violent } \\
\text { Not violent }\end{array}$ & $\begin{array}{c}29(12.2) \\
52(6.7) \\
\end{array}$ & $\begin{array}{l}208(87.8) \\
722(93.3) \\
\end{array}$ \\
\hline $\begin{array}{l}\text { 1. } \mathrm{X}^{2} \\
\text { 2. } \mathrm{X}^{2}= \\
\text { 3. } \mathrm{X}^{2}= \\
\text { 4. } \mathrm{X}^{2}= \\
\text { 5. } \mathrm{X}^{2}=\end{array}$ & $\begin{array}{l}, d f=1, p=0.793 \\
4, d f=1, p=, p=0.116 \\
5, d f=1, p=, p=0.294 \\
6, d f=1, p=, p=0.24 \\
, d f=1, p=, p=0.006^{*}(p<0\end{array}$ & 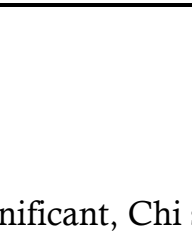 & sed in th & \\
\hline
\end{tabular}

\begin{tabular}{|c|c|c|c|c|}
\hline \multirow[t]{2}{*}{ Spearman's rho } & $\begin{array}{l}\text { Knowledge } \\
\text { score }\end{array}$ & $\begin{array}{c}\text { Correlation } \\
\text { Coefficient } \\
\text { Sig. (2-tailed) } \\
\text { N }\end{array}$ & $\begin{array}{c}\text { Knowledge } \\
\text { score } \\
1.000 \\
\cdot \\
1011\end{array}$ & $\begin{array}{c}\text { Attitude score } \\
-.077\left(^{*}\right) \\
.014 \\
1011\end{array}$ \\
\hline & $\begin{array}{l}\text { Attitude } \\
\text { score }\end{array}$ & $\begin{array}{c}\text { Correlation } \\
\text { Coefficient } \\
\text { Sig. (2-tailed) } \\
\text { N }\end{array}$ & $\begin{array}{c}. .077\left(^{*}\right) \\
.014 \\
1011\end{array}$ & $\begin{array}{c}1.000 \\
\cdot \\
1011\end{array}$ \\
\hline
\end{tabular}

\section{DISCUSSION}

\section{Subject characteristics}

The characteristics of participants described, reflect changes in nursing education for example earlier generation of nurses were almost exclusively female, now there are increasing numbers of male nursing students. Understandably students are many years junior to nursing staff. One study of mental health literacy in Australia has found significant differences only related to respondent age [22]. Besides in recent years, in nursing curriculum, the greater emphasis on psychiatry education is given than few years back when current staffs were students. The students' respondents in this study belonged to nursing colleges affiliated with medical colleges where mostly post graduate psychiatry department exist leading to better clinical exposure to the students; while many staff were trained in rural nursing schools where such facilities were not available leading to disadvantage.

More students have reported that they had psychiatric problems in the past while reports of psychiatric illness in family members were almost similar Compared to staff, students were more confident in helping the patients with psychiatric illness because of differences described earlier. Beside their knowledge was relatively fresh. 


\section{Knowledge about schizophrenia}

Out of all participants, $55.4 \%$ of nursing students and $30.6 \%$ of nursing staff correctly named disorder as "Schizophrenia" in the case vignette. In a study [23] in general community in Australia reported 27\% had correctly identified disorder. Other common wrong responses were psychosis, depression, mental illness and stress. Although most respondents recognized that the vignette depicted a disorder, many failed to exactly name that. In both the groups, most of them considered that the patient required professional help.

\section{Knowledge about psychiatric disorders: True/ false questions}

Knowledge level of nursing students was almost similar to nursing staff on these 10 true/false knowledge questions. As regards some of the items, knowledge of the both groups was quite good (75-90\%) like genetic etiology of schizophrenia, and most mentally ill are not violent. In contrast many studies in general community consider that endorsing genetic etiology of schizophrenia is more stigmatizing and increase in the desire for social distance from people with schizophrenia was found as genetic factors seem non modifiable factor [24-25,28]. Most studies on mental health literacy perceived mentally ill violent [26-31]. This is one of the most important factors that determine a person's attitude towards schizophrenia as regards to social distance. This knowledge keeps the respondents open to interaction with mentally ill without fear of harm. The groups' knowledge for certain other items were also good (correct responses between $50-65 \%$ ) like psychotropic drugs are mostly non-addictive. Though $56 \%$ believed the psychotropic drugs non-addictive and hence would advise patients for taking the same, however significant minority still believed that these medications would be addictive. For the remaining items knowledge level was not satisfactory (correct responses being $<30 \%$ ); the most important items being permanent memory loss due to ECT, desirability of treatment on OPD bases and not in mental hospital.

\section{Who can help patient with Schizophrenia}

Psychiatrist, clinical psychologist and nurses were considered as helpful to patient of schizophrenia by most of nursing students and nursing staff. This is because in the current mental health service scenario in the state; psychiatrist, nurses and clinical psychologist are available human resources to whom they are exposed. This finding was similar to study of Jorm mentioned earlier. Family doctor and social workers were also considered helpful though less frequently. Although there is advocacy of integration of mental health in primary health care, there is not much momentum in this direction. Social workers in particular are not visible in mental health field because of their scarcity. Pharmacist, homeopath doctors and ayurvedic doctors were considered helpful by very less participants in both the groups. The former are many a time perceived as mere dispenser of medications prescribed by doctors. At times they provide medications without prescription which may harm patients. Although there are large number of practitioners of alternative medical systems like homeopath doctors and ayurvedic doctors, nursing personnel trend in allopathic system do not confide in them. In a study of mental health in Ireland, 2007; 74\% considered General Practitioners, 11\% considered Psychiatrist and 10\% felt Psychologist as most helpful people for mentally ill [32]. In a study by NHS (2011) also; 85\% of people considered General Practitioners as most helpful professional for mental health problem [33]. In our study also around $80 \%$ of respondents said that family doctor is helpful for patient with schizophrenia.

As anywhere in the world, in India also large majorities are religious believers, and engage into prayers, religious activities like fast, offering, visiting religious place etc. Traditional healing practices are also very prevalent. Up to $70 \%$ mentally ill visit traditional healers before visiting professionals. Although in India several saints or god men preach large audience, one to one psychotherapy like encounters are less common, hence few respondents considered them helpful. Traditional healers especially engage into rituals involving physical torture, demanding large sum of money are perceived as harmful, hence many respondents in both the groups considered them so.

\section{What can help patient with Schizophrenia}

Although medications were considered helpful, there was ignorance regarding specific medications that can be helpful like antipsychotics (only by around $40 \%$ in both the groups). This is reflected in endorsing 
anti-anxiety and sedative medications more frequently compared to the more specific antipsychotic medications. More than $70 \%$ considered antidepressants as helpful; this may be due to lack of clarity in specific diagnosis and effective drug treatment. In a Jorm study antidepressants and antipsychotics were considered helpful by $38 \%$ and $23 \%$ of respondents respectively but this can be understood as study was in general community. Clearly not useful medications like analgesics and antibiotics were also considered useful by significant proportion of respondents. In a study, only $15.6 \%$ of urban and $34.4 \%$ of the rural population reported that they would like to go to a psychiatrist when they or their family members are suffering from mental illness [34].

In a study, the professionals gave much high ratings than the public to the helpfulness of antidepressants for depression, and of antipsychotics and admission to a psychiatric ward for schizophrenia. Conversely, the public tended to give much more favorable ratings to vitamins and minerals and special diets for both depression and schizophrenia, and to reading self-help books for schizophrenia [35]. Life style activities like yoga/meditation, exercise were also considered helpful by many. Similar finding were there in Jorm's study. In India yoga and meditation of various kinds are becoming popular with wide media coverage. There are many scientific evidences in favor of yoga and meditation to reduce stress and anxiety but its usefulness in disorder like schizophrenia is limited. Hypnosis and CBT were considered useful up to by $60 \%$ of respondents. This is because of perceived magic like effects of hypnosis. Its endorsement by up to $60 \%$ reflects their ignorance. In India ECT is still practiced widely and commonly especially in severe or acutely ill patients. This has been reflected by its endorsement in around 70\% of respondents. In Jorm's study, ECT was considered harmful by $66 \%$ of respondents.

In India, cultural beliefs related to nutrition and diseases are quite common for example spicy food makes person more irritable and angry, almond increases memory and mental peace. Avoidance of certain foods in management of many diseases is considered useful especially in ayurveda. Hence, even though there are not enough scientific evidences; many have considered vitamins and special diets helpful. Hospitalization in a general hospital as well as a mental hospital was considered useful; the former more frequently so. In the jorm's study hospitalization was considered harmful by $51 \%$ of respondents. Modern psychiatric practice emphasizes treatment of psychiatric disorders in non restrictive environments like general hospitals or OPD based treatment in community mental health centers. These respondents almost equally favor treatment in mental hospital without being aware of poor living conditions, human right violations and stigma associated with it.

\section{Attitude towards schizophrenia}

For items like living in neighborhood, socializing and making friendship with schizophrenia patient, both students and staff had positive attitude; however for working together with person with schizophrenia only $50-65 \%$ of respondents were ready. Respondents' attitude for fifth item that "readiness to marry within family of schizophrenia" was negative. But there was no statistically significant difference in attitude between respondents having and not having psychiatric illness to self and in family. This is contrast to other studies showing positive attitude in respondents who have psychiatric illness to self and in family. The stigma of mental illness can be reduced by education and experience, and an examination of attitudes towards mental illness should be included in medical training [29]. Contact with individuals who have mental illnesses, and education that replaces myth with fact, can decrease stigmatization and positively affect attitudes [30-33].

In nursing students, attitude towards schizophrenia was significantly positive $(p<0.05)$ as compared to nursing staff. From this it can be concluded that participants who had experience of working with psychiatric patients during their posting in psychiatric ward have positive attitudes. Even though nursing staff was currently working in different department of hospital, but their lack of work experience in psychiatry department was reflected in their negative attitude. This finding is similar to another study [36] but contrary to findings of other study [37]. In a study in Jordan [37] on nursing students positive attitudes towards mental illness were observed, previous contact with psychiatric patients was associated with positive attitudes, and demographic characteristics were not. Our findings are consistent with above study for nursing students. One study in Korea found that there is a significant difference in the nurses' student psychiatric nursing experience and their attitudes towards mental illness. The nurses who had 3-4 weeks of 
student psychiatric nursing experience had a significantly higher mean score for Benevolence than nurses whose student psychiatric experience had been less than 1 week $(p<0.05)$ [38]. Many studies showed that education about, and experience working with, mental illness may assist the development of more positive attitudes towards mental illness [39-41].

For more intimate relationship like marriage few respondents were ready (Students 5.9\% and staff $11.4 \%$ ). In both the groups around $30 \%$ totally denied for such relationship. In one study, Negative views of mental illness were widespread, with as many as $96.5 \%$ believing that people with mental illness are dangerous because of their violent behavior. Most would not tolerate even basic social contacts with a mentally ill person: $82.7 \%$ would be afraid to have a conversation with a mentally ill person and only $16.9 \%$ would consider marrying one [41]. Perception and knowledge of nursing students and the nursing staff on this topic is important as they directly deal with patients and their relatives, and they are also involved in disseminating health information. A negative attitude is known hindrance to providing quality service to mentally or physically ill persons. In studies of nurses, attitudes were significantly more negative towards people with mental disorders and co-workers returning after psychiatric illnesses than to those with diabetes [11, 42-44]. Many Studies show negative attitudes towards schizophrenia on parameters we examined in our study [16, 45-46]. Individuals who knew someone who received treatment for a mental health problem, or who had personally received treatment, were more likely to endorse biological theories of causality and positive -attitudes than those individuals without this familiarity to mental health problems [47-48].

\section{Knowledge and Attitude: Relationship}

Many published studies reported that merely increasing knowledge about Mental Health Problems doesn't have large impact on attitude for people suffering from psychiatric illness but systematic training can change attitude. Esterberg noted that Knowledge and social distance scores were not significantly correlated [18]. Angermeyer found that while there was an increase in the mental health literacy of the public, the desire for social distance from people with major depression and schizophrenia remained unchanged or even increased [28]. Authors have studied that greater knowledge was associated with lessdistancing attitudes [46]. Kitchener and Jorm claim that Mental Health First Aid (MHFA) training is able to increases knowledge, reduce stigma and increase supportive reactions in terms of mental health [12].

\section{Strengths of the Study}

- It is its own kind of study in India till date up to our knowledge.

- It was having large sample size and systematically inquiring who can help, what can help and attitude towards patients with schizophrenia.

- Results point to definite areas of knowledge deficits which can help more targeted educational interventions.

\section{Limitations}

Focus of this study has been Schizophrenia; however depression, anxiety disorders, somatization disorder and alcohol use disorder are more common in general health care. If the study had more in-depth inquiry into these disorders, it would have been more desirable.

\section{Implications and future recommendations}

Mental health educational sessions with young paramedical personnel will be useful approach for improving the attitudes towards mental illness. Still large number of sample can be taken in future study so we can get more data and plan the future strategy to improve knowledge and change the attitude of nursing personnel towards psychiatric disorders. 


\section{CONCLUSIONS}

This study provides a baseline of knowledge and attitudes of nursing students and nursing staff towards mental illnesses in Gujarat. It will enable future educational interventions to be evaluated and comparison to be made with other hospitals, states and countries. As psychiatric illnesses are increasing day by day, we have to plan to change attitudes of baseline health professional like nursing students and nursing staff towards mentally ill patients which ultimately benefit the community. We should also think for implementing practical psychiatric curriculum more thoroughly in nursing teaching to make future nurses more aware about psychiatric illnesses and their positive outcome. It also signifies the need of developing program to spread awareness of mental health and psychiatric illnesses in nursing personnel.

\section{REFERENCES}

1. Jorm AF, Korten AE, Jacomb PA, Christensen H, Rodgers B, Pollitt P: "Mental health literacy": a survey of the public's ability to recognise mental disorders and their beliefs about the effectiveness of treatment. The Med J Austr 1997;166(4):182-6.

2. Crisp AH, Gelder MG, Rix S, Meltzer HI, Rowlands OJ. Stigmatisation of people with mental illnesses. Br J Psychiatry 2000;177:4-7.

3. Caldwell TM, Jorm AF. Mental health nurses' beliefs about interventions for schizophrenia and depression: a comparison with psychiatrists and the public.Aust N Z J Psychiatry 2000;34:602-11.

4. Gureje O, Lasebikan VO, Ephraim-Oluwanuga O, Olley BO,Kola L. Community study of knowledge of and attitude to mental illness in Nigeria. Br J Psychiatry 2005;186:436-41.

5. Jorm AF, Korten AE, Jacomb PA, et al. Helpfulness of interventions for mental disorders: beliefs of health professionals compared with the general public.Br J Psychiatry 1997;171:233-7.

6. Link BG, Phelan JC, Bresnahan M, Stueve A, Pescosolido BA. Public conceptions of mental illness: labels, causes, dangerousness, and social distance. Am J Public Health 1999;89:1328-33.

7. Byrne, P. Stigma of mental illness and ways of diminishing it. Adv Psychiatr Treat 2000;6:65-72.

8. Esters, I., Cooker, P. and Ittenbach R. Effects of a unit of instruction in mental health on rural adolescents' conceptions of mental illness and attitudes about seeking help, in U.K. Adolescence 1998;33(130):469-76.

9. Pinfold V, Toulmin H, Thornicroft G, Huxley P, Farmer P, Graham T. Reducing psychiatric stigma and discrimination: evaluation of educational interventions in UK secondary schools. Br J Psychiatry 2003; 182:342-6.

10. Wolff G, Pathare S, Craig T, Leff J. Public education for community care: a new approach. Br J Psychiatry. 1996; 168:441-7.

11. Chambers M, Guise V, Välimäki M. Nurses' attitudes to mental illness: a comparison of a sample of nurses from five European countries. Int J Nurs Stud 2010;47:350- 62.

12. Kitchener BA, Jorm AF: Mental health first aid training for the public: evaluation of effects on knowledge, attitudes and helping behavior. BMC psychiatry 2002; 2:10.

13. Christoph Lauber, Vladeta Ajdacic-Gross, Nadja Fritschi, Niklaus Stulz and Wulf Rössler. Mental health literacy in an educational elite - an online survey among university students. BMC Public Health 2005; 5:44

14. Jadhav S, Littlewood R, Ryder AG, Chakraborty A, Jain S, Barua M. Stigmatization of severe mental illness in India: Against the simple industrialization hypothesis. Indian J Psychiatry 2007;49(3):189-94.

15. Murthy RS. Stigma is universal but experiences are local. World Psychiatry 2002;1(1):28-30.

16. Sabah S, Marie B, Saad AH, Jenkins R. Public perception of mental health in Iraq. Int J Ment Health Syst 2010;4:26

17. Lam AY, Jorm AF, Wong DF. Mental health first aid training for the Chinese community in Melbourne, Australia: effects on knowledge about and attitudes toward people with mental illness. Int J Ment Health Syst $2010 ; 24 ; 4: 18$.

18. Estrerberg, M L ; Compton M T ; McGhee R ; Shim R; Hochman K. Knowledge about Schizophrenia and Social Distance toward Individuals with Schizophrenia: A Survey among Predominantly Low-Income, Urban, African American Community Members. J Psychiatr Pract 2008;14(2):86-93.

19. Angermeyer MC, Matschinger H. Causal beliefs and attitudes to people with schizophrenia: Trend analysis based on data from two population surveys in Germany. Br J Psychiatry 2005;186:331-4. 
20. Kermode M, Bowen K, Arole S, Joag K, Jorm AF: Community beliefs about causes and risks for mental disorders: a mental health literacy survey in a rural area of Maharashtra, India. Int J Soc Psychiatry 2006; 56(6):606-22.

21. McCann TV, Lu S, Berryman C. Mental health literacy of Australian Bachelor of Nursing students: a longitudinal study. J Psychiatr Ment Health Nurs 2009;16(1):61-7.

22. Louise F, Liana L, Griffiths K, Jorm A, Helen C. Age differences in mental health literacy. BMC Public Health 2008;8:125:10.

23. Jorm AF: Mental health literacy. Public knowledge and beliefs about mental disorders. Br J Psychiatry 2000; 177:396-401.

24. Schomerus G, Schwahn C, Holzinger A, Corrigan PW, Grabe HJ, Carta MG, Angermeyer MC. Evolution of public attitudes about mental illness: a systematic review and meta-analysis. Acta Psychiatr Scand 2012;125(6):440-52.

25. Read J, Haslam N, Sayce L, Davies E. Prejudice and schizophrenia: A review of the mental illness is an illness like any other approach. Acta Psychiatr Scand 2006;114:303-18.

26. Magliano L, De Rosa C, Fiorillo A, Malangone C, Maj M ,.Perception of patients' unpredictability and beliefs on the causes and consequences of schizophrenia- a community survey. National Mental Health Project Working Group. Soc Psych Psychiatr Epidemiol 2004;39(5):410-6.

27. Link BG, Phelan JC, Bresnahan M, Stueve A, Pescosolido BA. Public conceptions of mental illness: labels, causes, dangerousness, and social distance. Am J Public Health 1999;89:1328-33.

28. Angermeyer MC, Holzinger A, Matschinger H. Mental health literacy and attitude towards people with mentalillness: A trend analysis based on population surveys in the eastern part of Germany. Eur Psychiatry 2009;24(4):225-32.

29. Leiderman EA, Vazquez G, Candela B, Bonifacio A, Bruscoli N, Juan I. Public knowledge, beliefs and attitudes towards patients with schizophrenia: Buenos Aires. Social Psych Psychiatr Epidemiol 2011;46(4):281-90.

30. Kitchener BA, Jorm AF. Mental Health First Aid: An international programme for early intervention. Early Interv Psychiatry 2008;2;55-61.

31. Kobau R, Dilorio C, Chapman D, Delvecchio P, SAMHSA/CDC Mental Illness Stigma Panel Members. Attitudes about mental illness and its treatment: validation of a generic scale for public health surveillance of mental illness associated stigma. Commun Ment Health J 2010;46(2):164-76.

32. Health Service Executive: Mental Health in Ireland: Awareness and Attitudes 2007. ISBN 978-0-9553854-2-1

33. Attitude to mental illness, NHS (National Health Service) 2011 Survey Reports; Version 1; Date of Publication: 8 June 2011: NHS Information Center Mental Health and Community.

34. Kishore J, Gupta A, Jiloha RC, Bantman P. Myths, beliefs and perceptions about mental disorders and health-seeking behavior in Delhi, India. Indian J Psychiatry 2011;53(4);324-9.

35. Jorm AF, Korten AE, Jacomb PA, Rodgers B, Pollitt P, Christensen H, Henderson S. Helpfulness of interventions for mental disorders: beliefs of health professionals compared with the general public. $\mathrm{Br}$ Psychiatry 1996;168(5):652-8.

36. Hugo M. Mental health professionals' attitudes toward people who have experienced a mental health disorder. J Psychiatr Ment Health Nurs 2001;8(5):419-25.

37. Shaher Hamaideh H, Mudallal R. Attitudes of Jordanian nursing students towards mental illness: the effect of teaching and contact on attitudes change. College Student Journal, June 2009 accessed online http://www.freepatentsonline.com/article/College-Student-Journal/201608595.html on 12 Sept.2011.

38. Park YS. A Study of the Attitudes of Nonpsychiatric Registered Nurses towards Mental Illness and Mental Patients. J Nurs Acad Soc 1973;3(2):31-44.

39. Emrich T, Thompson C, Moore G. Positive attitude: an essential element for effective care of people with mental illnesses. J Psychosoc Nurs Ment Health Serv 2003;41(5):18-25.

40. Read J, Law A. The relationship between causal beliefs and contact with users of mental health services to attitudes to mental illness. Int J Soc Psychiatry 1999;45(3):216-9.

41. Foster K, Usher K, Baker JA, Gadai S, Ali S. Mental health workers' attitudes toward mental illness in Fiji. Austr J Adv Nurs 2008;25(3):72-9.

42. Angermeyer $M$, Matschinger $H$. The stigma of mental illness: effects of labelling on public attitudes towards people with mental disorder. Acta Psychiatr Scand 2003;108:304-9.

43. Yeo SG, Parker G, Yap HL, Mahendran R. Mental health literacy beliefs. A comparison of psychiatric trained nurses and enrolled nurses in Singapore. J Psychosoc Nurs Ment Health Serv 2003;41(3):34-41.

44. Glozier N, Hough C, Henderson M, Holland-Elliott K. I Attitudes of nursing staff towards co-workers returning from psychiatric and physical illnesses. Int J Soc Psychiatry 2006;52(6):525-34. 
45. Thara R, Kamath S, Kumar S. Women with Schizophrenia and Broken Marriages -Doubly Disadvantaged? Part II: Family Perspective. Int J Social Psychiatry 2003;49(3):225-32.

46. Stuart H, Arboleda-Flórez J. Community attitudes toward people with schizophrenia. Can J Psychiatry 2001;46(3):245-52.

47. Martinez MA. Lay causal theories and familiarity with mental illness. Senior Thesis in Psychology.Advisor: Susan Nolen-Hoeksema April 19, 2010 accessed http://www.yale.edu/psychdus/Senior_Essays_files/f.pdf on 27 May, 2012.

48. Francis C, Pirkis J, Dunt D, Warwick Blood R, Davis C. Improving Mental Health Literacy: A Review of the Literature. Centre for Health Program Evaluation. Melbourne, Australia ; 2002.

Acknowledgements - Dept. of Psychiatry: B. J. Medical College, Ahmedabad; Govt. Medical College, Bhavnagar; SMIMER Medical College, Surat; Govt. Medical College, Surat; M.P. Shah Medical College, Jamnagar; P.D.U. Medical College, Rajkot; Dr. Ajay Chauhan, Superintendent, Hospital for Mental Health, Ahmedabad; All Participants and Resource Persons.

Source of Funding - MHPC Project was sponsored by State Mental Health Authority, Gujarat Government. Conflict of Interest - Nil

\section{APPENDIX \\ A case vignette}

A 44 years old male has difficulties since 10 years. He does not work, remains withdrawn, does not take bath for days, and wanders aimlessly, talks to himself, standing at cross roads. He hears voices of two persons who comment on his thoughts and activities continuously. He believes that his neighbors are against him, spy constantly, keep watch on him and they are plotting to trap him. Neighbors send dirty messages through TV and newspapers carry bad stories about him.

This paper was originally published in the Indian Journal of Mental Health - Issue 3(3), 2016.

There were numerous errors in the paper which were missed in the proofs by the authors and the editors due to an inadvertent oversight on the part of the journal. The paper is hence republished in the current issue as a new original research paper with all corrections in place and shall bear the citations of the current paper.

The original paper published in the previous issue of the journal stands retracted and the paper must be cited using the current journal issue and page numbers. 